JURNAL PENDIDIKAN, p-ISSN 2715-095X, e-ISSN 2686-5041

Volume 29, No.2, Juli 2020 (127-142)

Online: http://journal. univetbantara. ac. id/index. php/jp

\title{
Penerapan Metode Cooperative Integrated Reading Compasition untuk Meningkatkan Motivasi dan Hasil Belajar Bahasa Indonesia Kelas X-IPS 2 SMA Negeri 1 GemolongTahun Pelajaran 2019/2020
}

\author{
Giyono \\ Guru SMA Negeri 1 Gemolong, Kabupaten Sragen
}

\begin{abstract}
Abstrak : Tujuan penelitian ini adalah untuk mendeskripsikan, menjelaskan pelaksanaan model pembelajaran Cooperative Integrated Reading Compasition (CIRC) dan dengan penerapan model pembelajaran tersebut untuk meningkatkan motivasi dan hasil belajar bahasa Indonesia kelas X IPS 2 SMA Negeri 1 Gemolong. Penelitian ini adalah penelitian tindakan kelas yang dilaksanakan dalam 2 siklus atau dua pertemuan dan tiap pertemuan terdiri dari perencanaan, tindakan, pengamatan, dan refleksi. Subjek penelitian adalah peserta didik kelas X IPS 2 SMA Negeri 1 Gemolong pada semester 1 tahun pelajaran 2019/2020.Sumber data diperoleh dari guru, peserta didik, tempat, dan peristiwa berlangsungnya aktivitas pembelajaran dan dokumentasi.Teknik dan alat pengumpulan data menggunakan observasi.Validitas data menggunakan trianggulasi sumber data.Analisis data menggunakan analisis kualitatif. Hasil penelitian menunjukkan bahwa sebelum tindakan penelitian kelas, rata-rata kemampuan siswa dalam menciptakan kembali teks anekdot mendapat skor 68, setelah diadakan siklus I mendapat skor rata-rata 72,89 dan setelah siklus II rata-rata mendapat skor 81,73 , Sementara keaktifan dalam pembelajaran teks anekdot juga meningkat setiap pertemuan pada siklusnya, siklus I rata-rata 68,83 , siklus II rata-rata 85,28 . Berdasarkan hasil observasi kompetensi keterampilan juga mengalami peningkatan sehingga hal tersebut mempengaruhi kemampuan menciptakan kembali teks anekdot padasiswa kelas X IPS 2 SMA Negeri 1 Gemolong. Berdasarkan hasil penelitian di atas, dapat disimpulkan bahwa penerapan Cooperative Integrated Reading Compasition (CIRC) dapat meningkatkan motivasi siswadan meningkatkan belajar pada Siswa Kelas X IPS 2 Semester 1 SMA Negeri 1 Gemolong Tahun Pelajaran 2019/2020.
\end{abstract}

Kata-kata Kunci : Metode CIRC, meningkatan motivasi dan hasil belajar.

\section{The Implementation of Cooperative Integrated Reading Compasition Increased Motivation and Result to Study Indonesian Language in Class X IPS 2 SMA Negeri 1 Gemolong in the Academic Year of 2019/2020}

\section{Giyono}

\author{
Teacher of SMA Negeri 1 Gemolong Sragen
}

\begin{abstract}
Abstrac: The purpose of this research is to describe, explain implementation Cooperative Integrated Reading Compasition learning model and with that learning model application to increase motivation and resultto study bahasa Indonesia for the student of XIPS 2 SMA Negeri 1 Gemolong. This research is class action research which executed in 2 cyles or two meeting and every meeting consist of planning, action, observation, and reflection. This subject of research is the students of X IPS 2 SMA Negeri 1 Gemolong at semester 1 period 2019/2020. Data source is abtained by teacher, student, place, and learning activity and documentation event be helding. Technique and data's gathering devide use observation. The data's validity uses data source triangulation. Data's analysis uses qualitative analysis. The result of research
\end{abstract}


indicates that before the class research action, the student's ability to reinventing anecdote text to reach score 68, after cycle I is held, getting average score 72,89 and after cycle II average get score 81,73, white being active in anecdot text learning also increasing in every meeting at the cycle, averaging cycle $I$ is 68,83, averaging cycle II is 85,28. Based on the result of teacher's performance observaton also increasing until that influence the student's reinventing anecdote text, especially the student's of X IPS 2 SMA Negeri 1 Gemolong. Based on the result of research above, we can conclude that application of Cooperative Integrated Reading Compasition can increasing motivation to reinventing anecdote text and increasing ability the student's of XIPS 2 semester 1 SMA Negeri 1 Gemolong, in period 2019/2020

Key words : CIRC methodes motivation and result to study increase

\section{Pendahuluan}

Pembelajaran bahasa Indonesia diarahkan pada peningkatan kemampuan siswa untuk berkomunikasi dalam bahasa Indonesia dengan baik dan benar, baik secara lisan maupun tulisan, serta menumbuhkan apresiasi terhadap hasil karya kesastraan manusia Indonesia. Pembelajara bahasa perlu dikembangkan menjadi pembelajaran ketrampilan berbahasa bukan hanya pembelajaran tentang tata bahasa. Aktivitas pembelajaran di SMA Negeri 1 Gemolong Kabupaten Sragen saat ini masih kurang mendorong siswa untuk aktif dan berpikir kritis, terutama pembelajaran pada aspek menulis.Menulis merupakan satu bentuk keterampilan berbahasa yang paling akhir setelah keterampilan mendengarkan, berbicara, dan membaca.Dibanding ketiganya, kemampuan menulis lebih sulit dikuasai bahkan oleh penutur asli bahasa yang bersangkuta sekalipun.Keterampilan menulis memang menjadi satu keterampilan berbahasa yang paling sulit untuk dikuasai.Hal ini disebabkan adanya dua unsur yang harus dikuasai oleh penulis, yaitu unsur bahasa dan nonbahasa. Unsur bahasa merupakan unsur yang berkaitan dengan asek tata bahasa, seperti ejaan, struktur kalimat, kohesi dan koherensi, serta unsur kebahasaan yang lain. Sementara itu, unsur nonbahasa yang dijadikan ide atau gagasan dalam sebuah tulisan meliputi unsur diluar aspek tata bahasa, seperti pengetahuan dan pengalaman penulis.Keterampilan menulis menjadi bertambah sulit apabila penulis diharuskan menggunakan kaidah tata bahasa sesuai EYD. Pada umumnya siswa mengalami hambatan atau kesulitan ketika diberi tugas menulis dengan menggunakan bahasa baku sesuai EYD. Kondisi tersebut juga terjadi di SMA Negeri 1 Gemolong Sragen, ketika penulis menyampaikan materi teks anekdot dengan bahasa yang tepat dan baku di kelas X-IPS 2.

Fakta di atas menunjukkan kualitas proses pembelajaran yang dilaksanakan guru kurang optimal. Berdasarkan pengalaman mengajar selama ini dan dikuasai dengan teman sejawat, serta wawanara secara acak dengan beberapa siswa dapat ditarik kesimpulan awal bahwa rendahnya keterampilan siswa dalam menulis teks anekdot dengan bahasa yang tepat dan baku disebabkan oleh beberapa faktor, antara lain : 1) pembelajaran menulis yang 
dilakukan guru bahasa Indonesia di SMA Negeri 1 Gemolong Sragen masih menggunakan metode konvensional ceramah dan berpusat pada guru sehingga siswa mengalami kesulitan dan jenuh dalam belajar, 2) siswa kurang tertarik pada pembelajara menulis, 3) siswa mengalami kesulitan dalam menentukan kata atau kalimat baku yang digunakan, dan 4) guru belum menemukan metode tepat dalam pembelajaran menulis yang menarik dan menyenangkan siswa.

Sejak diterapkannya kuikulum 2013, SMA Negeri 1 Gemolong Sragen telah berupaya untuk menerapkan semaksimal mungkin terutama jurusan Ilmu Pengetahuan Sosial, namun karena terbentur banyaknya keterbatasan dan adanya beberapa kendala yang dihadapi seperti: sarana dan prasarana, kurangnya pengalaman para guru tentang pelaksanaan kurikulum 2013 serta kondisi pada siswa, maka penarapan kurikulum masih terdapat kekurangan. Dalam konsepnya, kurikulum 2013 lebih menekankan pemberdayaan siswa sebagai subyeknpembelajar dan proses pembelajaran berpusat pada siswa (student contered), guru diposisikan sebagai motivator dan fasilitator. Namun pada kenyataannya, di SMA Negeri 1 Gemolong Sragen masih terbiasa menggunkan system belajar yang berpusat pada guru (teacher contered) berupa ceramah, guru lebih berorientasi pada pencapaian materi yang padat dan harus diselesaikan dalam waktu yang cukup singkat. Metode konvesional tersebut menyebabkan kurang adanya interaktif edukatif antara guru dengan siswa. Apabila siswa "dipaksa" untuk selalu menerima materi secara terus menerus maka siswa akan mengantuk dan jenuh. Kejenuhan siswa dalam belajar akan berakibat fatal yaitu rendahnya motivasi belajar yang berakibat pada hasil belajar siswa tidak akan tercapai secara optmal.Berdasarkan pengalaman penulis selama mengajar materi menulis anekdot, banyak siswa yang kurang mampu menulis. Hal itu dapat dilihat daftar yang diperoleh siswa dengan rincian nilai terendah 59 , nilai tertinggi 76 , nilai rata-rata kelas hanya mencapai 68, sedangkan ketuntasan klasikal mencapai 69,53\%.

Berdasarkan kenyataan tersebut, perlu diterapkan suatu metode pembelajaran yang dapat membantu situasi pembelajaran lebih fleksibel, efektif.dan kooperatif sehingga diharapkan mutu proses pembelajaran dapat meningkatkan dan pada akhirnya dapat meningkatkan kemampuan siswa dalam menulis anekdot. Metode kooperatif tipe CIRC (Cooperative Integrated Reading Composition) merupakan salah satu metode mengajar yang dapat diterapkan oleh guru bahasa Indonesia untuk mengatasi permasalahan motivasi dan hasil belajar siswa.Metode pembelajaran CIRC merupakan metode pembelajaran yang menggunakan prinsip belajar kelompok. Metode ini dilaksanakan dengan membagi siswa dalam kelompok yang masing-masing terdiri atas 4-5 siswa heterogen, kemudian tiap kelompok diberi bahan bacaan, dan dari bahan bacaan tersebut siswa diharapkan dapat memperoleh pengetahuan sehingga mampu menyelesaikan masalah yang dihadapi. Metode CIRC mendorong siswa leluasa berpendapat, siswa dilatih bekerjasama dan menghargai pendapat orang lain, membuat suasana pembelajaran yang kooperatif antar siswa dan antar siswa dengan guru. CIRL merupakan metode belajar kelompok yang dihubungkan dengan kemampuan membaca dan menulis, merupakan kemampuan dasar yang harus dimiliki siswa sejak mengenal dunia pendidikan. 
Dalam pembelajaran bahasa Indonesia kompetensi dasar menciptakan kembali teks anekdot dengan memperhatikan struktur dan kebahasaan yang disampaikan khususnya di kelas X-IPS 2 SMA Negeri 1 Gemolong, yang cara penyampainnya membutuhkan peran siswa secara aktif dalam proses pembelajaran. Partisipasi siswa tersebut terlihat dalam kegiatan melakukan kerja dalam kelompok dan peran serta dalam kegiatan pemecahan masalah dalam kelompok.Kegiatan ini menuntut siswa mempunyai bekal materi yang diperoleh dari membaca dan mencari sumber belajar.Melaui penerapan metode CIRL diharapkan materi ini dapat diserap dengan baik oleh siswa, sehingga memberikan hasil yang optimal dalam mempelajari materi terkait selanjutnya.Perumusan masalah di dalam penelitian ini adalah "Apakah penerapan metode CIRC dalam pembelajaran dapat meningkatkan motivasi dan hasil belajar bahasa Indonesia materi menciptakan kembali tek anekdot dengan memerhatikan struktur dan kebahasaan bagi siswa kelas X-IPS 2 SMA Negeri 1 Gemolong Sragen".Pada dasarnya penelitian ini diharapkan dapat berhasil dengan baik, yaitu dapat mencapai tujuan penelitian secara maksimal, menghasilkan laporan yang sistematis. Adapun manfaat yang diambil dari penelitian ini bagi siswa dapat meningkatkan keaktifan / motivasi siswayaitu mengajukan pertanyaan, mengambil giliran, berbagai tugas, dan mendengarkan secara aktif, meningkatkan kemampuan siswadalam menciptakan kembali suatu teks. Sedangkan bagi guru memberikan alternatif metode pembelajaran yang lain bagi guru Bahasa Indonesia untuk meningkatkan kemampuannya, serta bagi sekolah dapat meningkatkan kualitas sekolah melalui peningkatan motivasi dan kemampuan siswadan kinerja guru.

Sudah banyak para ahli psikologi pendidikan dan psikologi perkembangan yang membahas tentang motivasi dalam pembelajaran.Sedemikian banyaknya pembahasan tentang motivasi dalam pembelajaran itu telah menghasilkan definisi motivasi yang banyak pula.Namun demikian pada intinya, motivasi dapat diartikan sebagai (1) Dorongan yang timbul pada diri seseorang, secara disadari atau tidak disadari, untuk melakukan suatu tindakan dengan tujuan tertentu. (2) Usaha-usaha yang dapat menyebabkan seseorang atau kelompok orang tertentu tergerak melakukan sesuatu karena ingin mencapai tujuan yang ingin dicapai (Mohammad Asrori, 2007). Sedangkan menurut Uno (2007), motivasi dapat diartikan sebagai dorongan internal dan eksternal dalam diri seseorang yang diindikasikan dengan adanya, hasrat dan minat, dorongan dan kebutuhan, harapan dan cita-cita, penghargaan dan penghormatan. Motivasi berasal dari kata "motif" yang diartikan sebagai daya upaya yang mendorong seseorang untuk melakukan sesuatu. Menurut Sardiman (2006:73) motif merupakan daya penggerak dari dalam untuk melakukan kegaiatan untuk mencapai tujuan.Motivasi adalah perubahan energi dalam diri (pribadi) seseorang yang ditandai dengan timbulnya perasaan dan reaksi untuk mencapai tujuan (Hamalik, 1992:173).Dalam Sardiman (2006:73) motivasi adalah perubahan energi dalam diri seseorangyang ditandai dengan munculnya "felling" dan 
didahului dengan tanggapan terhadap adanya tujuan.Menurut Mulyasa (dalam Giyono, 2019: 3) motivasi adalah tenaga pendorong atau penarik yang menyebabkan adanya tingkah laku ke arah suatu tujuan tertentu. Peserta didik akan bersungguh-sungguh karena memiliki motivasi yang tinggi. Seorang siswa akan belajar bila ada faktor pendorongnya yang disebut motivasi.Dimyati dan Mudjiono (2002:80) mengutip pendapat Koeswara mengatakan bahwa siswa belajar karena didorong kekuatan mental, kekuatan mental itu berupa keinginan dan perhatian, kemauan, cita-cita di dalam diri seorang terkadang adanya keinginan yang mengaktifkan, menggerakkan, menyalurkan dan mengarahkan sikap dan perilaku individu dalam belajar. Jadi dapat disimpulkan bahwa motivasi belajar adalah keseluruhan daya penggerak di dalam diri siswayang menimbulkan kegiatan belajar menjamin kelangsungan dan memberikan arah pada kegiatan belajar sehingga tujuan yang dikehendaki dapat tercapai.Dalam motivasi belajar dorongan merupakan kekuatan mental untuk melakukan kegiatan dalam rangka pemenuhan harapan dan dorongan dalam hal ini adalah pencapaian tujuan.

Menurut Winkel (2005: 532), hasil belajar adalah suatu hasil usaha yang telah dicapai siswa yang mengadakan suatu kegatan pembelajaran di sekolah dan usaha yang dapat menghasilakn perubahan pengetahuan, sikap, dan tingkah laku. Hasil perubahan tersebut diwujudkan dengan nilai.Menurut Syah (2004: 141). "Hasil belajar adalah setiap macam perubahan yang khas sebagai hasil setelah belajar". Nana Syaodih (dalam Waryana 2020:57) menyatakan bahwa hasil belajar atau achievement merupakan realisasi atau pemekaran dari kecakapan-kecakapan potensial atau kapasitas yang dimiliki seseorang. Sedangkan dalam Kamus Besar Bahasa Indonesia,disebutkan bahwa hasil belajar adalah hasil usaha yang telah dicapai atau yang telah dikerjakan untuk mendapatkan suatu kecakapan dan kepandaian (Lukman, 1995: 768).Berdasarkan beberapa pendapat di atas, dapat disimpulkan bahwa hasil belajar adalah perubahan sikap, ringkah laku, kebiasaan dan perubahan kualitas penguasaan terhadap materi pembelajaran yang dapat diukur dan dievaluasi setelah menerima materi pembelajaran tertentu.Pengembangan CIRC dihasilkan dari sebuah analisis masalah-masalah tradisional dalam pengajaran, pelajaran membaca, menulis dan seni bahasa. Satu focus utama dari kegiatan-kegiatan CIRC adalah membuat penggunaan waktu lebih efektif. Para siswa bekerja di dalam tim-tim kooperatif, yang dikoordinasikan dengan pengajaran kelompok membaca, supaya dapat memenuhi tujuantujuan dalam bidang lain seperti pemahaman membaca, kosakata, pembacaan pesan dan ejaan. Slavin (2005: 56) menyatakan bahwa metode CIRC merupakan program gabungan membaca, menulis dengan menggunakan pembelajaran baru dalam pemahaman bacan dengan menulis, keberhasilan metode CIRC sangat bergantung pada keaktifan siswa. Ciriciri metode CIRC adalah: 1) Adanya satu tujuan; 2) Adanya tanggung jawab tiap individu; 3) Dalam satu kelompok mempunyai kesempatan yang sama untuk sukses; 4) Tidak ada kompetisi antara kelompok; 5) Tidak ada tugas khusus; 6) Menyesuaikan diri dengan kebuthan menjadi kewajiban tiap individu.Tujuan utama CIRC adalah menggunakan kelompok-kelompok kooperatif untuk membawa siswa mempelajari kemampuan memahami bacaan yang dapat diaplikasikan secara luas. CIRC terdiri atas tiga unsur 
penting: kegatan-kegiatan dasar terkait, pengajaran langsung pelajaran memahami bacan, seni berbahasa dan menulis terpadu (Slavin, 2005: 204).Menurut Slavin (2005: 106-107) langkah-langkah dalam pembelajaran kooperatif tipe CIRC adalah: 1) Membentuk kelompok yang anggotanya 4-5 orang yang secara heterogen; 2) Guru memberikan wacana sesuai dengan topic pembelajaran; 3) Siswa bekerja sama saling membacakan dan menemukan ide; 4) Mempersentasikan hasil kelompok; 5) Guru membuat kesimpulan bersama; dan 6) Penutup.Kelebihan metode CIRC siswa dapat memberikan tanggapannya secara bebas, dilatih untuk dapat bekerjasama dan menghargai pendapat orang lain. Kekurangan metode CIRC pada saat presentasi hanya siswa yang aktif yang tampil, memerlukan waktu yang relative lama, adanya kegiatan-kegiatan kelompok yang terkadang tidak berjalan sesuai harapan.Sesuai dengan silabus mata pelajaran bahasa Indonesia kelas X-IPS 2 SMA terdapat kompetensi dasar yang harus disampaikan yaitu menciptakan kembali teks anekdot dengan memperhatikan isi dan aspek kebahasaan.Agar lebih efektif dalam mencapai tujuan pembelajaran maka dalam pemberian materi menciptakan kembali teks anekdot dengan memperhatikan struktur dan kebahasaan. Mengingat dalam menulis teks anekdot harus sesuai dengan aturan baku EYD sehingga membutuhkan koreksi kebahasaan yang tepat, hal itu dapat dilakukan dengan baik apabila siswa dibekali tentang aturan baku dalam EYD dalam menulis teks anekdot. Hal-hal yang biasanya diperbaiki dalam menulis adalah ejaan, tanda baca, pilihan kata, dan keefektifan kalimat.Sebagian besar siswa mengalami kesulitan dalam menulis teks anekdot yang antara lain disebabkan oleh tingkat kesulitan materi yang cukup tinggi kondisi itu diperparah oleh rendahnya kualitas proses pembelajaran menulis yang dilakukan guru bahasa Indonesia yaitu metode pembelajaran masih konvensional ceramah dan berpusat pada guru sehingga siswa mengalami kesulitan dan jenuh dalam belajar dan kurang tertarik pada pembelajaran menulis.Untuk mengatasi kesulitan dalam proses pembalajaran dan lebih efektif maka diperlukan variasi metode dalam pembelajaran. Pembelajaran kooperatif metode CIRC merupakan salah satu metode pembelajaran yang dapat diterapkan untuk mengatasi masalah yang muncul dalam pembelajaran. Metode CIRC melatih siswa bekerjasama dan menghargai pendapat orang lain, saling memberi masukan, membuat suasana pembelajaran menyenangkan dan terjadi kerjasama positif antar siswa dan antara siswa dengan guru sehingga memperbesar peluang pencapaian hasil belajar yang lebih baik.

Kerangka berpikir dalam penelitian ini dapat diterangkan sebagai berikut : kondisi awal tindakan dilaksanakan, diperoleh gambaran (yang dilakukan pada kegiatan prasurvei dengan observasi, wawancara, dan angket) bahwa dalam pembelajaran menciptakan kembali teks anekdot yang berlangsung di SMA Negeri 1 Gemolong, (1) nilai kemampuan menciptakan kembali teks anekdot masih rendah, (2) guru menggunakan metode ceramah dan penugasan dalam menyampaikan materi sehingga siswa kurang dilibatkan secara aktif dalam pembelajaran, (3) siswakurang tertarik atau kurang senang dengan materi pelajaran 
menciptakan kembali teks anekdot karena mereka menganggap kurang bermanfaat dalam kehidupan nyata dan menganggap teks anekdot tersebut hanya teks asal-asalan. Dari kondisi ini, peneliti mencoba menawarkan pembelajaran kooperatif metode CIRC untuk pembelajaran menciptakan kembali teks anekdot.Pada metode pembelajaran ini para siswabekerja melalui enam tahap. Tahap pertama mengidentifikasi topik, tahap kedua merencanakan kerja sama, tahap ketiga implementasi, tahap empat analisis sintesis, tahap lima penyajian hasil akhir, dan tahap enam evaluasi. Untuk lebih jelasnya tentang kerangka berpikir pada penelitian ini dapat dilihat pada gambar berikut.

\begin{tabular}{|c|c|c|}
\hline Kondisi Awal & Tindakan & Kondisi Akhir \\
\hline$\downarrow$ & $\downarrow$ & $\downarrow$ \\
\hline $\begin{array}{l}\text { 1. Guru dalam proses } \\
\text { pembelajaran } \\
\text { menerapkan metode } \\
\text { konvensional } \\
\text { 2. Keaktifan siswadalam } \\
\text { pembelaiaran rendah }\end{array}$ & $\begin{array}{l}\text { Guru dalam } \\
\text { pembelajaran } \\
\text { menggunakan } \\
\text { metode Inquiri } \\
\text { Terbimbing }\end{array}$ & $\begin{array}{l}\text { 1. Guru dalam } \\
\text { pembelajaran lebih } \\
\text { kreatif dan variatif } \\
\text { 2. Kualitas proses } \\
\text { pembelajaran } \\
\text { meningkat }\end{array}$ \\
\hline $\begin{array}{l}\text { 3. Hasil belajar } \\
\text { siswarendah }\end{array}$ & & $\begin{array}{l}\text { 3. Aktivitas peserta didik } \\
\text { dalam pembelajaran } \\
\text { meningkat }\end{array}$ \\
\hline
\end{tabular}

Gambar 1. Kerangka Berpikir

Berdasarkan kajian teoritis dan kerangka berpikir, maka hipotesis penelitian ini dapat dirumuskan sebagai berikut: 1) Penerapan metode CIRC dapat meningkatkan keaktifan siswaselama pembelajaran, 2) Penerapan metode CIRC dapat meningkatkan motivasi siswaselama pembelajaran, 3) Penerapan metode CIRCdapat meningkatkan kemampuan siswa selama pembelajaran.

\section{Metode Penelitian}

Penelitian dilakukan di SMA Negeri 1 Gemolong, Sragen yang beralamat di Jalan Citrosancakan, Gemolong, Sragen.Sekolah ini mempunyai 27 kelas. Tindakan penelitian dilakukan di kelas X IPS 2 karena pada kelas ini terdapat permasalahan yang perlu segera diatasi untuk memperbaiki proses dan hasil belajar Bahasa Indonesia khususnya pada kompetensi dasar menciptakan kembali teks anekdot dan kebetulan penulis sebagai guru di kelas tersebut. Sehingga memudahkan untuk mendapatkan data yang diperlukan. Subyek penelitian ini adalah peserta didik kelas X IPS 2 SMA negeri 1 Gemolong tahun pelajaran 
2019-2020. Siswatersebut berjumlah 34 orang, dengan laki-laki sebanyak 10 orang dan perempuan sebanyak 22 orang. Sedangkan obyek penelitiannya adalah motivasi dan hasil belajar. Pembelajaran menciptakan kembali teks anekdot dengan menggunakan metode CIRC yang akan dilaksanakan berdasarkan Standar Kompetensi dan Kompetensi Dasar sesuai dengan kurikulum 2013 kelas X semester 1. Guru dalam hal ini bertindak sebagai mitra peneliti. Prosedur penelitian adalah suatu rangkaian tahap-tahap penelitian dari awal sampai akhir. Menurut Suharsini Arikunto (2004: 16) dalam pelaksanaan PTK ini, mekanisme kerjanya diwujudkan dalam bentuk siklus yang mencakup empat kegiatan, yaitu : (1) perencanaan, (2) pelaksanaan, (3) observasi, (4) analisis dan refleksi. Keempat kegiatan tersebut saling terkait dan secara urut membentuk sebuah siklus.Teknik pengumpulan data yang digunakan penulis adalah tes yang berbentuk obyektif maupun uraian digunakan untuk mengukur keberhasilan siswa dalam belajar.Penulis menggunakan jenis tes evaluasi yang berupa soal.Teknik ini digunakan untuk mengamati perkembangan yang dilakukan peserta didik sejak sebelum diberikan tindakan, pada saat pelaksanaan tindakan, sampai akhir tindakan.Kegiatan yang diamati meliputi pembelajaran menciptakan kembali teks anekdot yang dilakukan oleh guru sesuai RPP yang dibuat oleh peneliti dan guru.Peran peneliti dalam kegiatan ini adalah sebagai partisipan pasif.Hasil observasi didiskusikan dengan guru yang bersangkutan, kemudian dianalisis untuk mengetahui berbagai kelemahan yang ada dan untuk mencari solusi terhadap kelemahan tersebut.Hasil diskusi berupa solusi untuk berbagai kelemahan tersebut kemudian dilaksanakan dalam siklus berikutnya.Berikutnya adanya dokumentasi, yang berupa hasil tes siswadianalisis secara kuantitatif.Selanjutnya ditentukan nilai pengetahuan dengan peringkat tinggi, rendah, rerata, dan ketuntasan. Untuk nilai keterampilan juga meliputi nilai tinggi, rendah, dan rerata.

Validitas data yang digunakan dalam penelitian ini adalah teknik trianggulasi sumber data dan teknik trianggulasi metode. Trianggulasi sumber data yaitu menggali data yang sejenis dari berbagai sumber data yang berbeda. Peneliti menggali dari informan yang berbeda-beda posisinya dengan wawancara sehingga informasi dari informan satu dapat dibandingkan dengan informan lain. Selain itu, peneliti juga menggali data dari arsip atau dokumen, dan hasil observasi terhadap aktivitas pembelajaran yang dilakukan. Trianggulasi metode adalah menggali data yang sama dengan menggunakan metode pengumpulan data yang berbeda. Hal ini dilakukan untuk menggali data tentang pelaksanaan pembelajaran menciptakan kembali teks anekdot yang diperoleh dari metode wawancara dengan informan guru dan siswa, dari metode analisis dokumen berupa persiapan tertulis yang sudah dibuat oleh guru dan dari observasi pelaksanaan pembelajaran menganalisis teks negosiasi yang berlangsung.Teknik analisis data yang digunakan adalah dengan menganalisis secara deskriptif dan kualitatif. Menurut Suharsini Arikunto, dkk. (2008: 131132), analisis deskriptif adalah menganalisis data kuantitatif yang berupa nilai hasil belajar 
siswa. Teknik analisis deskriptif dapat digunakan untuk mengolah data yang berkaitan dengan menjumlah, merata-rata, mencari persentasi, dan menyajikan data secara menarik, mudah dibaca dan diikuti alur berpikirnya (tabel, grafik, chart). Teknik ini digunakan untuk membandingkan nilai tes antarsiklus.Peneliti membandingkan hasil sebelum dengan hasil pada akhir setiap siklus. Teknik analisis data berikutnya adalah secara kualitatif. Data kualitatif adalah data yang berupa informasi berbentuk kalimat yang memberikan gambaran tentang tingkat pemahaman (kognitif) siswa, pandangan atau sikap siswa terhadap metode belajar yang baru (afektif), dan aktivitas siswa dalam mengikuti pelajaran. Untuk data kualitatif yang berupa hasil wawancara baik wawancara peneliti dengan guru maupun peneliti dengan siswa, hasil pengamatan, dan angket, peneliti biasanya melakukan proses koding untuk mengorganisasi data. Tahapan proses koding adalah membuat matrik dari data yang terkumpul, memberi kode untuk masing-masing sel, membaca data secara menyeluruh dan menentukan sesuai tema, mengelompokkan masing-masing pernyataan ke dalam kotak-kotak sel, mengaitkan antara sel sehingga mengandung makna, membat interpretasi dari data yang terdapat dalam sel, dan mendeskripsikan secara jelas data dalam sel atau matrik sehingga menjadi suatu kesimpulan( Suharsimi Arikunto, dkk.2008:132. Hasil analisis deskriptif maupun analisis kualitatif dijadikan dasar dalam menyusun perencanaan tindakan untuk tahap berikutnya sesuai dengan siklus yang ada.Analisis data dilakukan bersamaan dan atau setelah pengumpulan data.

Indikator Keberhasilan dalam Penelitian Tindakan Kelas (PTK) yang dilakukan pada siswa kelas X IPS 2 SMA Negeri 1 Gemolong ukuran keberhasilan penelitian yang ingin dicapai yaitu meningkatnya motivasi dan kemampuan peserta didik dalam menciptakan kembali teks anekdot dengan menggunakan metode CIRC. Indikator yang digunakan untuk mengetahui peningkatan tersebut adalah keaktifan siswameningkat dengan tuntas belajar secara klasikal $(\geq 85 \%$ ), nilai pengetahuan pada akhir siklus minimal mencapai KKM ( $\geq 75 \%$ ), dan nilai keterampilan pada akhir siklus minimal mencapai KKM.

\section{Hasil Penelitian}

Kondisi awal pembelajaran menciptakan kembali teks anekdot dan tes kemampuan awal siswadalam menciptakan kembali teks anekdot pada kelas X IPS 2 masih rendah.Dalam pembelajaran guru masih menggunakan metode ceramah, pemberian contoh, dan penugasan. Akhirnya siswamerasa kurang tertarik terhadap materi menciptakan kembali teks anekdot. Muncullah permasalahan kurangnya keaktifan siswadalam kegiatan pembelajaran dan pencapaian hasil belajar yang kurang optimal. Hal ini menyebabkan hasil belajar rendah, yakni siswayang tuntas belajar hanya 32\% dengan rata-rata nilai di bawah KKM. Suasana gaduh yang disebabkan peserta didik kurang serius dalam mengikuti pembelajaran.Siswatidak memperhatikan penjelasan guru, kurang merespon pertanyaan yang diberikan guru dalam apersepsi, membuat suasana kurang kondusif, ada yang mengantuk, dan bahkan ada beberapa siswa yang berbicara dengan teman sebangku serta 
motivasi belajar sangat rendah. Dengan demikian kondisi ini perlu ditindaklanjuti untuk materi menciptakan kembali teks anekdot agar siswalebih termotivasi melalui CIRC. Alasan lainnya, bahwa selama ini metode yang digunakan oleh guru dalam proses pembelajaran masih didominasi dengan metode ceramah (monoton) dan pemberian tugas. Peran guru yang masih mendominasi pelajaran sehingga kurang memberi kesempatan kepada siswauntuk lebih banyak mendalami teks anekdot. Siswakurang dapat memahami dalam menciptakan kembali teks anekdot.

Dari hasil uji pratindakan yang diberikan dengan lima soal uraian yang berkaitan dengan menciptakan kembali teks anekdot hanya 10 siswa (34\%) yang memperoleh nilai di atas Kriteria Ketuntasan Minimal (KKM), peserta didik yang lainnya 24 anak $(67,75 \%)$ memperoleh nilai di bawah KKM. Nilai rata-rata yang dicapai juga rendah, yaitu 68 masih di bawah KKM yang ditetapkan dalam kurikulum. Berdasarkan hasil tes yang telah dilakukan tersebut diketahui bahwa kemampuan menciptakan kembali teks anekdot.siswarendah dan perlu ditingkatkan sesuai dengan tujuan dan harapan yang sudah ditetapkan dalam KTSP SMA Negeri 1 Gemolong, yaitu nilai ketuntasan minimal adalah 75 dan nilai ketuntasan klasikal minimal 85\%.

Pada penelitian ini menggunakan dua siklus, siklus I dan siklus II. Untuk pertemuan pertama/ siklus I ini peneliti melakukan kegiatan pembelajaran, pengamatan aktifitas terhadap siswa, dan pengamatan kompetensi keterampilan. Pengamatan keaktifan siswa selama mengikuti pembelajaran sebelum menggunakan metode CIRC adalah sebagai berikut: a) Siswa aktif menjawab apersepsi guru berjumlah 22 siswa atau 64,71\%; b) Siswa aktifmemperhatikan penjelasan guru 23 siswa atau 67,65\%; c) Siswa terlibat aktif dalam diskusi 25 siswa atau 73,53\%; d) Siswa aktif bertanya jawab 23 siswa atau 67,65\%; e) Siswa aktif menyimpulkan materi 24 siswa atau $70,59 \%$. Rata-rata persentase motivasi belajar siswa sebesar $68,83 \%$.Maka dapat disimpulkan bahwa rata-rata persentase motivasi belajar siswa belum mencapai batas minimal yang ditemntuan, yaitu $80 \%$.

Sedangkan Observasi terhadap kompetensi keterampilan belajar siswa dalam pembelajaranmateri menciptakan kembali teks anekdot sebelum menggunakan metode CIRC dapat diuraikan sebagai berikut: a) Rata-rata kemampuan siswa menganalisis kebahasaan isi teks sebesar 73,82 ; b) Rata-rata kemampuan siswa menyampaikan ide kepada kelompok sebesar 74,12; c) Rata-rata kemampuan siswa berbicara dalam kelompok sebesar 74,79; d) Nilai rata-rata kompetensi keterampilan sebesar 74,25. Untuk berikutnya hasil tes dari materi menciptakan kembali teks anekdot, bahwa hasil belajar siswa dalam pembelajaran sebelum menggunakan metode CIRCdengan memperhatikan struktur dan kebahasaan yang hasilnya diuraikan sebagai berikut: nilai terendah 65, nilai tertinggi 80 , nilai rata-rata kelas 72,94, dan ketuntasan klasikal sebesar 73,53\%.Berdasarkan uraian hasil pengamatan guru dalam pelaksanaan pembelajaran sebelum menggunkan metode CIRC 
secara keseluruhan hasil observasi belum terlihat hasil yang diharapkan dan perlu adanya beberapa aspek yang harus diperbaiki.

Pada pertemuan kedua atau siklus II peneliti melakukan perbaikan-perbaikan pada pertemuan kesatu.Dari kegiatan pembelajaran pada pertemuan kedua diperoleh data sebagai berikut. Hasil pengamatan keaktifan siswa selama mengikuti pembelajaran materi menulis teks anekdot dengan memerhatikan struktur dan kebahasaan setelah menggunakan metode CIRC adalah sebagai berikut: a) Siswa aktif menjawab apersepsi guru berjumlah 30 siswa atau 88,24\%; b) Siswa aktif memperhatikan penjelasan guru 29 siswa atau 85,29\%; c) Siswa terlibat aktif dalam diskusi 30 siswa atau 88,24\%; d) Siswa aktif bertanya jawab 28 siswa atau 82,35\%; e) Siswa aktif menyimpulkan materi 28 siswa atau 82,35\%. Rata-rata persentase motivasi belajar siswa sebesar 85,29\%.Untuk lebih jelasnya uraian di atas dideskripsikan dalam bentuk tabel di bawah ini:

Tabel 1. Hasil Observasi Motivasi Belajar Siswa Siklus II

\begin{tabular}{llll}
\hline No & \multicolumn{1}{c}{ Uraian } & \multicolumn{2}{l}{ Persentase(\%) } \\
\hline 1 & Siswa aktif dalam apersepsi & 30 & 88,24 \\
2 & Siswa aktif memperhatikan penjelasan guru & 29 & 85,29 \\
3 & Siswa terlibat aktif dalam diskusi & 30 & 88,24 \\
4 & Siswa aktif bertanya jawab & 28 & 82,35 \\
5 & Siswa aktif menyimpulkan materi & 28 & 82,35 \\
\hline Rata-rata & 29 & 85,29 \\
\hline
\end{tabular}

Dari tabel di atas dapat disimpulkan bahwa rata-rata persentase motivasi belajar siswa sudah mencapai batas minimal yang ditentuan, yaitu $80 \%$. Hasil observasi terhadap nilai rata-rata keterampilan belajar siswa setelah menggunakan metode CIRC dalam pembelajaran materi menulis teks anekdot dengan memperhatikan struktur dan kebahasaan yang hasilnya secara rinci diuraikan sebagai berikut: a) Rata-rata kemampuan siswa menganalisis kebahasaan isi teks sebesar 78,82; b) Rata-rata kemampuan siswa menyampaikan ide kepada kelompok sebesar 76,18; c) Rata-rata kemampuan siswa berbicara dalam kelompok sebesar 80,59; d) Nilai rata-rata kompetensi keterampilan sebesar 78,53.Untuk lebih jelasnya uraian di atas dideskripsikan dalam bentuk tabel di bawah ini:

Tabel 2. Hasil Observasi Kompetensi Keterampilan Siswa Siklus II

\begin{tabular}{|c|c|c|}
\hline No & \multicolumn{2}{|c|}{ Nilai Rata-rata } \\
\hline 1 & Kemampuan siswa menganalisis kebahasaan isi teks & 78,82 \\
\hline 2 & Kemampuan siswa menyampaikan ide kepada kelompok & 76,18 \\
\hline 3 & Kemampuan siswa berbicara dalam kelompok & 80,59 \\
\hline $\mathrm{R}$ & ta-rata & \\
\hline
\end{tabular}


Deskripsi terhadap hasil belajar siswa setelah menggunakan metode CIRC (Cooperaive Integrated Reading Compossition) dalam pembelajaran materi menulis teks anekdot dengan memperhatikan struktur dan kebahasaan yang hasilnya diuraikan sebagai berikut: nilai terendah 70 , nilai tertinggi 90 , nilai rata-rata kelas 81,73 , dan ketuntasan klasikal sebesar 85,28\%.

Tabel 3: Hasil Tes Siklus II

\begin{tabular}{llc}
\hline No & Uraian & Nilai \\
\hline 1 & Nilai terendah & 70 \\
2 & Nilai Tertinggi & 90 \\
3 & Nilai rata-rata & 81,73 \\
4 & Ketuntasan & $85,28 \%$ \\
\hline
\end{tabular}

\section{Pembahasan}

Berdasarkan hasil survei diperoleh gambaran bahwa motivasi belajar siswa pada Siklus I di saat belummenggunakan metode CIRC siswa terlihat kurang antusias mengikuti pembelajaran. Hal tersebut disebabkan siswa tidak tertarik dengan metode mangajar guru.Metode yang biasa digunakan adalah ceramah dan menyuruh siswa mengerjakan tugas misalnya mengkonversi teks ke dalam bentuk drama atau mengerjakan LKS.Hal ini menunjukkan motivasi belajar siswa rendah, sehingga berdampak pada hasil belajar rendah.Setelah pembelajaran berlangsung pada Siklus II atau saat guru menerapkan metode CIRC, siswa tampak termotivasi sejak awal pembelajaran dengan aktif dalam apersepsi, aktif memperhatikan penjelasan guru, dan aktif dalam diskusi. Siswa terlibat aktif ambil bagian dalam proses pembelajaran, seperti munculnya inisiatif menjawab pertanyaan yang diajukan oleh guru maupun lemparan pertanyaan dari teman yang lain.Perubahan positif terhadap motivasi siswa dalam pelaksanaan pembelajaran Sklus I dan Sklus II pada mata pelajaran bahasa Indonesia materi menciptakan kembali teks anekdot dengan memperhatikan struktur dan kebahasaan yang hasilnya dideskripsikan dalam bentuk tabel di bawah ini:

Tabel 4. HasilPerbandingan Motivasi Belajar Siswa Siklus I dan Sklus II

\begin{tabular}{clcc}
\hline & \multirow{2}{*}{ No } & \multicolumn{2}{c}{ Persentase Motivasi } \\
\cline { 3 - 4 } & & \multicolumn{2}{c}{ Siswa } \\
\hline 1 & Siswa aktif dalam apersepsi & Siklus II \\
2 & Siswa aktif memperhatikan penjelasan guru & $67,71 \%$ & $88,24 \%$ \\
3 & Siswa terlibat aktif dalam diskusi & $73,53 \%$ & $85,29 \%$ \\
4 & Siswa aktif bertanya jawab & $67,65 \%$ & $82,35 \%$
\end{tabular}




\begin{tabular}{ccc}
$5 \quad$ Siswa aktif menyimpulkan materi & $70,59 \%$ & $82,35 \%$ \\
\hline Rata-rata & $68,83 \%$ & $85,29 \%$
\end{tabular}

Berdasarkan data tabel di atas dapat disimpulkan bahwa telah terjadi dampak positif terhadap motivasi belajar siswa sebagai berikut: a) Siswa aktif menjawab apersepsi guru terjadi perubahan positif dengan selisih sebesar $17,64 \%$, yaitu motivasi belajar siswa saat siklus I atau sebelum menggunakan metode CIRC sebesar $64,71 \%$ dan setelah siklus II atau guru menggunakan metode CIRC menjadi $88,24 \%$, b) Siswa aktif memperhatikan penjelasan guru terjadi perubahan positif dengan selisih sebesar $17,64 \%$, yaitu motivasi belajar siswa sebelum menggunakan metode CIRC sebesar $67,65 \%$ dan setelah guru menggunakan metode CIRC menjadi $85,29 \%$, c) Siswa terlibat aktif dalam diskusi terjadi perubahan positif dengan selisih sebesar $14,71 \%$, yaitu motivasi belajar siswa sebelum menggunakan metode CIRC sebesar 73,53\% dan setelah guru menggunakan metode CIRC menjadi $88,24 \%$, d) Siswa aktif bertanya jawab terjadi perubahan positif dengan selisih sebesar $14,70 \%$, yaitu motivasi belajar siswa sebelum menggunakan metode CIRC sebesar $67,65 \%$ dan setelah guru menggunakan metode CIRC menjadi $82,35 \%$, e) Siswa aktif menyimpulkan materi terjadi perubahan positif dengan selisih sebesar $17,65 \%$, yaitu motivasi belajar siswa sebelum menggunakan metode CIRC sebesar 70,59\% dan setelah guru menggunakan metode CIRC menjadi 82,35\%, f) Rata-rata persentase motivasi belajar siswa terjadi perubahan positif dengan selisih sebesar $16,46 \%$, yaitumotivasi belajar siswa pada siklus I atau sebelum menggunakan metode CIRC sebesar $68,83 \%$ dan pada siklus II atau setelah guru menggunakan metode CIRC menjadi 85,29\%.Hal tersebut menggambarkan bahwa telah terjadi peningkatan motivasi belajar siswa dengan menggunakan metode CIRC. Sebelum penerapan metode CIRC ini dilaksanakan pada siklus I siswa terlibat kurang antusias mengikuti pembelajaran. Hal tersebut disebabkan metode yang digunakan guru hanya ceramah dan siswa mengerjakan soal LKS. Sehingga tidak ada bimbingan dari guru yang berakibat terhadap keterampilan siswa rendah dan berdampak pada hasil belajar rendah.Setelah guru menerapkan metode CIRC dalam pembelajaran pada siklus II, siswa tampak termotivasi sejak awal pembelajaran dengan aktif dalam apersepsi, aktif menyampaikan pendapat tentang permasalahan yang dihadapi siswa atau temannya. Siswa terlibat aktif ambil bagian dalam proses pembelajaran, seperti munculnya inisiatif menjawab pertanyaan yang diajukan oleh guru maupun lemparan pertanyaan dari teman yang lain.

Tabel 5. Hasil Perbandingan Kompetensi Keterampilan Siswa Siklus I dan II

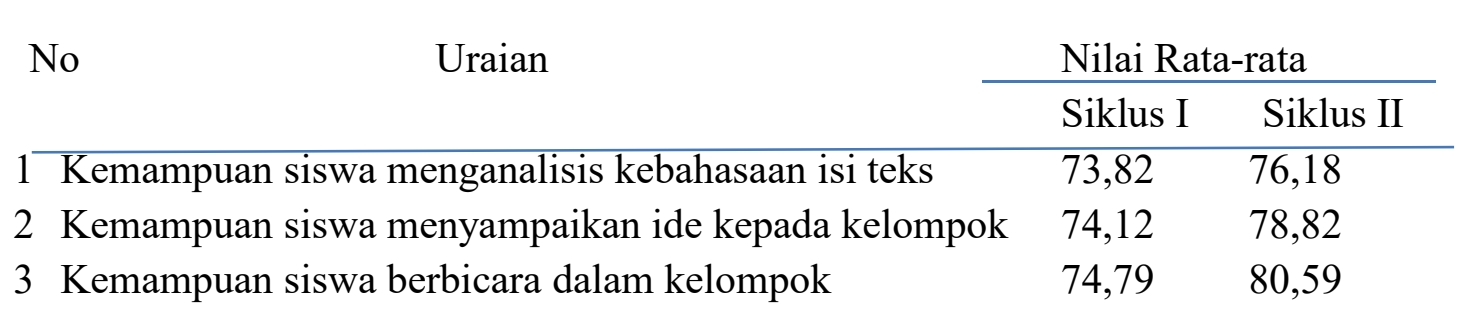




\begin{tabular}{lll}
\hline Rata-rata & 74,25 & 78,53 \\
\hline
\end{tabular}

Berdasarkan data tabel di atas dapat disimpukan bahwa telah terjadi perubahan positif atau dampak positif terhadap kompetensi keterampilan siswa sebagai berikut: a) Kemampuan siswa menganalisis kebahasaan isi teks terjadi perubahan positif dengan selisih sebesar 2,36 poin, yaitu keterampilan siswa sebelum menggunakan metode CIRC sebesar 73,82 dan setelah guru setelah guru menggunakan metode CIRC menjadi 76,18, b) Kemampuan siswa menyampaikan ide kepada kelompokterjadi perubahan positif dengan selisih sebesar 4,70 poin, yaitu keterampilan siswa sebelum menggunakan metode CIRC sebesar 74,12 dan setelah guru menggunakan metode CIRC menjadi 78,82, c) Kemampuan siswa berbicara dalam kelompokterjadi perubahan positif dengan selisih sebesar 5,8 poin, yaitu keterampilan siswa sebelum menggunakan metode CIRC sebesar 74,79 dan setelah guru menggunakan metode CIRC menjadi 80,59 , d) Nilai rata-rata kompetensi keterampilan terjadi perubahan positif dengan selisih sebesar 4,28 poin, yaitu keterampilan siswa sebelum menggunakan metode CIRC sebesar 74,25 dan setelah guru menggunakan metode CIRC menjadi 78,53. Hal tersebut menggambarkan bahwa telah terjadi peningkatan kompetensi keterampilan dengan menggunakan metode CIRC.

Sedangkan perbandingan siklus I dan siklus II pada hasil belajar juga akan terlihat nyata. Sebelum penerapan metode CIRC ini dilaksanakan atau pembelajaran siklus I, siswa terlibat kurang antusias mengikuti pembelajaran. Hal tersebut disebabkan metode yang digunakan guru hanya ceramah dan siswa mengerjakan soal LKS. Sehingga tidak ada bimbingan dari guru yang berakibat terhadap hasil belajar siswa rendah. Setelah guru menerapkan metode CIRC dalam pembelajaran atau siklus II, siswa tampak termotivasi sejak awal pembelajaran dengan aktif dalam apersepsi, aktif menyampaikan pendapat tentang permasalahan yang dihadapi siswa atau temannya. Siswa terlibat aktif ambil bagian dalam proses pembelajaran, seperti munculnya inisiatif menjawab pertanyaan yang diajukan oleh guru maupun lemparan pertanyaan dari teman yang lain serta menulis di papan tulis.Perubahan positif terhadap hasil belajar siswa dalam pelaksanaan pembelajaran siklus I dan siklus II, atau sebelum guru menggunakan dan sesudah guru menggunakan metode CIRC pada mata pelajaran bahasa Indonesia materi menciptakan kembali teks anekdot dengan memperhatikan struktur dan kebahasaan yang hasilnya dideskripsikan dalam bentuk tabel di bawah ini.

Tabel 6. Perbandingan Nilai Siswa Siklus I dan Siklus II

\begin{tabular}{llll}
\hline & No $\quad$ Uraian & \multicolumn{2}{c}{ Hasil Belajar Siswa } \\
\cline { 3 - 3 } & Siklus I & Siklus II \\
\hline
\end{tabular}




$\begin{array}{llcc}1 & \text { Nilai Terendah } & 65 & 70 \\ 2 & \text { Nilai Tertinggi } & 80 & 90 \\ 3 & \text { Nilai Rata-rata } & 72,89 & 81,73 \\ 4 & \text { Ketuntasan Klasikal } & 75,53 \% & 85,28 \%\end{array}$

Berdasarkan data tabel di atas dapat disimpukan bahwa telah terjadi dampak positif terhadap hasil belajar siswa sebagai berikut: a) Nilai rata-rata kelas terjadi perubahan positif dengan selisih sebesar 8,53 poin, yaitu nilai rata-rata kelassiklus I atau sebelum menggunakan metode CIRC sebesar 72,94 dan pada saat siklus II atau setelah guru menggunakan metode CIRC menjadi 81,73 , b) Ketuntasan belajar secara klasikal terjadi perubahan positif dengan selisih sebesar $11,76 \%$ yaitu ketuntasan belajar siswa sebelum menggunakan metode CIRC sebesar 73,53\% dan setelah guru menggunakan metode CIRC menjadi $85,28 \%$. Hal tersebut menggambarkan bahwa telah terjadi peningkatan nilai siswa dengan menggunakan metode CIRC.

Berdasarkan perubahan hasil penerapan metode CIRC dapat disimpulkan bahwa secara keseluruhan guru telah berhasil menerapkan metode pembelajaran CIRC dalam rangka mengatasi permasalahan motivasi dan hasil belajar siswa dalam pembelajaran bahasa Indonesia dengan mencapai indicator keberhasilan, sehinga penerapan metode CIRC sangat tepat sebagai solusi mengatasi permasalahan proses pembelajaran bahasa Indonesia.

\section{Simpulan dan Saran}

Berdasarkan keseluruhan hasil yang telah diperoleh dalam pelaksanaan pembelajaran pada siklus II dengan menggunakan metode CIRC dalam pembelajaran materi "Menciptakan kembali teks anekdot dengan memperhatikan struktur dan kebahasaan" berdampak positif terhadap perubahan motivasi dan hasil belajar siswa kelas X-IPS 2 SMA Negeri 1 Gemolong Kabupaten Sragen dari kondisi sebelum dan setelah penerapan metode CIRL sebagai berikut: 1) Rata-rata persentase motivasi belajar siswa terjadi perubahan positif dengan selisih sebesar $16,46 \%$, yaitu motivasi belajar siswa sebelum menggunakan metode CIRC sebesar $68,83 \%$ dan setelah guru menggunakan metode CIRC menjadi $85,28 \%$; 2) Nilai rata-rata kompetensi keterampilan terjadi perubahan positif dengan selisih sebesar 4,28 poin, yaitu keterampilan siswa sebelum menggunakan metode CIRC sebesar 74,25 dan setelah guru menggunakan metode CIRC menjadi 78,53 ; 3) NIlai rata-rata kelas terjadi perubahan positif dengan selisih sebesar 8,53 poin, yaitu niai rata-rata kelas sebelum menggunakan metode CIRC sebesar 72,94 dan setelah guru menggunakan metode CIRC menjadi 81,73 ; 4) Ketuntasan belajar secara klasikal terjadi perubahan positif dengan selisih sebesar $11,76 \%$, yaitu ketuntasan belajar siswa sebelum menggunakan metode CIRC sebesar 73,53\% dan setelah guru menggunakan metode CIRC menjadi 85,28\%.

Berdasarkan simpulan tersebut di atas, maka penulis menyampaikan beberapa saran, antara lain: 1) Dalam proses pembelajaran, guru hendaknya memperhatika dan 
mempertimbangkan pendekatan dan model pembelajaranyang tepat, yaitu model pembelajaran yang melibatkan peran serta dan keatifan siswa, salah satu model pembelajaran yang digunakan adalah pembelajaran kooperatif CIRC; 2) Guru sebagai pengajar hendaknya mengkaji lebih dalam permasalahan yang timbul selama proses pembelajaran sehingga siswa lebih aktif dan kuaitas pembelajaran lebih baik; 3) Siswa hendaknya tidak tergantung pada materi yang diberikan oleh guru, tetapi lebih aktif mencari informasi materi dari sumber-sumber lain; 4) Bagi siswa yang kurang paham terhadap materi hendaknya aktif bertanya kepada guru atau teman yang lebih paham; 5) Hal-hal yang menjadi kesulitan dalam belajar sebaiknya dikonsultasikan kepada guru.

\section{Daftar Rujukan}

Asrori, Mohammad. (2007). Psikologi Pembelajaran. Bandung: CV Wacana Prima.

Dimyati dan Mudjiono. (2002). Belajar dan Pembelajaran. Jakarta: PT Rineka Cipta.

Giyono.(2019). Penerapan Metode Group Investigation untuk Meningkatkan Motivasi dan

Kemampuan Menganalisis Teks Negosiasi Peserta Didik Kelas X MIPA 1 SMA

Negeri 1 Gemolong Tahun Pelajaran 2018/2019. Jurnal Pendidikan, Volume 28

Nomor 1, Maret 2019. Hal:1-16.

Hamalik,Oemar. (1992). Teori Motivasi dan Pengukurannya. Bandung: Angkasa.

Lukman, Ali dkk. (1995). Kamus Besar Bahasa Indonesia. Jakarta: Balai Pustaka.

Sardiman, A.M. (2006). Interaksi dan Motivasi Belajar Mengajar. Jakarta: PT Raja Grafindo Persada.

Slavin, R.E. (2005). Cooperative Learning, Teory Research and Practise. Boston:Allyn and Bacon, Edisi Terjemahan.

Suhartini Arikunto, Suharjono, dan Supardi. (2008). Penelitian Tindakan Kelas. Jakarta: Bumi Aksara.

Syah, Muhibin. (2004). Psikologi Pendidikan suatu Pendekatan Baru.Bandung:Remaja Roda Karya.

Uno, Hamzah B. (2007). Teori Motivasi dan Pengukurannya(Analisis di Bidang Pendidikan). Jakarta: Bumi Aksara.

Waryana (2020).Upaya Meningkatkan Minat dan Hasil Belajar IPS Materi Perubahan Sosial Budaya melalui Penerapan Model Pembelajaran Kooperatif Tipe Make a Match pada Siswa Kelas IX A SMP Veteran 1 Manyaran Tahun Pelajaran 2019/2020. Jurnal Pendidikan. Volume 29 Nomor 1, Maret 2020. Hal:67-76. 